\title{
7
}

\section{BEDAH BUKU \\ Teori Kekuasaan, Teori Sosial, dan Ilmuwan Sosial Indonesia}

\author{
Ivanovich Agusta
}

Upaya untuk menggabungkan pembahasan ketiga buku ini (Dhakidae, 2003; Stewart, 2001; Hadiz dan Dhakidae, eds, 2005) sekaligus didasari tiga kebutuhan berikut. Pertama, buku Stewart membahas perkembangan konsep kekuasaan (power) dari masa modernitas ${ }^{1}$ sampai masa modernitas akhir. ${ }^{2}$ State of the art tentang konsep kekuasaan ini bisa menjadi metode untuk menyoroti isi buku Dhakide serta Hadiz dan Dhakidae (eds.) secara lebih kritis. Dalam konteks ini, dari karya Stewart terutama akan diambil pelajaran tentang beragam konsep kekuasaan, bukan konsep kekuasaan menurut pandangan Stewart sendiri. Hal ini disebabkan, Stewart memposisikan dirinya dalam kelompok sosiolog modern, sementara saya lebih menyetujui posisi sosiolog pasca modern dalam menggunakan konsep kekuasaan. Dari sini mungkin akan tumbuh kritik pembacaan yang berbeda tentang perkembangan konsep kekuasaan, minimal dalam pembahasan tentang lokalitas dan kebutuhan suatu ketunggalan pandangan mendasar.

Kedua, ketiga buku tersebut merupakan karya-karya ilmiah terbaru (di atas tahun 2000), sehingga sudah selayaknya dibedah lebih lanjut untuk memperkaya pengetahuan kritis tentang topik kekuasaan, perkembangan ilmu sosial, dan perkembangan posisi ilmuwan sosial (yang menjadi warganegara) Indonesia. Seorang kolega, ketika membicarakan buku Dhakidae serta Hadiz dan Dhakidae (eds.), berkata, "Tanpa membaca kedua buku ini, kesimpulan umum dari keduanya sudah bisa kita ketahui atau kita ramalkan, yaitu bahwa ilmu sosial dan ilmuwan sosial dikoooptasi oleh kekuasaan negara. Tapi kita ingin mengetahui rincian argumen yang dibangun di dalamnya. Dan untuk itulah kita perlu membacanya secara detil".

\footnotetext{
${ }^{1}$ Dalam khasanah perkembangan teori-teori sosiologi di Amerika Serikat, masa ini dimulai sekitar tahun 1920-an (Wallace dan Wolf, 1999; Sharrock, Hughes dan Martin, 2003)

2 Penggunaan istilah masa modernitas akhir (late modernity) menjadi salah satu ciri khas sosiolog yang menolak istilah pasca modernitas (post-modernity), karena memandang masa kini (masa sejak 1970-an hingga kini) masih memiliki logika modern yang tersusun atau tertata sistematis. Di antaranya A. Giddens, J. Habermas, termasuk Stewart sendiri yang sempat duduk di London School of Economics. Mereka menganggap pascamodernitas tidak didasarkan pada suatu rasionalitas yang tetap, sehingga sulit untuk dijadikan landasan penyusunan pemikiran ilmiah. Penggunaan istilah modernitas akhir dalam buku Stewart sudah mendudukkan posisinya dalam perkembangan teori-teori sosiologi mutakhir, yaitu pada posisi teori-teori sosiologi modern.
} 
Ketiga, saya khawatir penulisan buku Dhakidae serta Hadiz dan Dhakidae (eds.) masih dihinggapi oleh konsep modern tentang kekuasaan, yang mengimpitkan konsep kekuasaan itu dengan konsep dominasi. Mungkin ini didasari argumen, bahwa kondisi modernitas akhir (atau pascamodernitas) memang sudah terjadi di Eropa dan Amerika Serikat, namun belum terjadi di Indonesia. Menurut saya sendiri, argumen ini lemah, karena para penulis yang menjadi akademisi ini sudah merupakan sosok-sosok yang masuk ke dalam ruang dan waktu modernitas akhir (kelas menengah) di tengah-tengah masyarakat (terutama pedesaan dan wilayah terpencil) yang masih berkutat pada ruang dan waktu modernitas. Olah karenanya, saya masih heran membaca Dhakidae (2003) menggunakan juga kerangka teori modern, yaitu neofasisme, bersama-sama dengan arkeologi pengetahuan ala Foucaoult, untuk menganalisis posisi cendekiawan semasa Orde Baru. Dalam Hadiz dan Dhakidae (eds.), mungkin karena merupakan kumpulan tulisan dari banyak ilmuwan sosial dengan beragam posisi mazhab keilmuan, memang sudah ada yang menggunakan konsep kekuasaan ala modernitas akhir, misalnya pada Ariel Heryanto. Namun di sinipun, konsep kekuasaan masih dipraktekkan sebagai kekuasaan yang meliputi (power over) sesuatu atau seseorang, yang akan berujung pada konsep kekuasaan sebagai dominasi. Begitu pula Meutia Ganie-Rohman hendak mengemukakan resistensi ilmuwan sosial yang tergabung dalam LSM (lembaga swadaya masyarakat, $\mathrm{NGO}=$ non-government organization), namun di dalamnya kekuasaan tetap hanya diandaikan sebagai dominasi. Di dalam karya Stewart, definisi kekuasaan ini berada di sisi yang berlawanan (bahkan mungkin dianggapnya sudah ketinggalan jaman jika dirunut dari state of the art konsep kekuasaan) dari konsep kekuasaan sebagai pemberdayaan (empowerment). Pada konsep terakhir, muncul kekuasaan terhadap (power to) sesuatu atau seseorang, yang memungkinkan pemerdekaan diri (oleh lapisan bawah).

\section{Teori Kekuasaan}

Angus Stewart hendak menggali ciri-ciri dan peluang konsep kekuasaan yang baru, sebagai alternatif dalam menganalisis kondisi masyarakat (atau kelompok sosial) dalam ruang dan waktu modernitas akhir. Mula-mula ia telah berhasil menunjukkan perbedaan penting antara konsep kekuasaan dan dominasi (yang sudah mulai berkelindan minimal sejak akhir 1960-an melalui kerja Talcott Pasons, dan melembaga mulai tahun 1970-an melalui kerja antara lain Anthony Giddens dan Michelle Foucault). Kekuasaan dalam bentuk dominasi merupakan wujud dari kekuasaan meliputi sesuatu atau seseorang. Selanjutnya ia merumuskan politik transformatif pada masa modernitas akhir saat ini. Ia menunjuk pada adanya konsep ruang publik (public sphere), kewargaan (citizenship), dan gerakan sosial sebagai perwujudan kekuasaan dalam bentuk pemberdayaan. Di sini muncul kekuasaan terhadap (power to) sesuatu atau seseorang, yang bisa dimiliki lapisan bawah sekalipun.

Buku ini dimulai dari bab Pendahuluan (Introduction) yang menceritakan latar belakang penyusunan buku dan rancangan per bab. Buku diakhiri dengan bab 
Kesimpulan (Conclusion) yang merangkum dua bagian besar buku ini, diakhiri pertanyaan tentang tertantangnya peran negara (state) oleh beragam persoalan global, yang diikuti serta merta oleh peran non-negara dalam ruang publik, kewargaan dan gerakan sosial.

Penyusunan bab-bab dalam buku ini terbagi dua Bagian (Parts), yang nampaknya mengikuti pola pemikiran Mann (sebagaimana dikutip Stewart, 2001) tentang kekuasaan. Bagian pertama merujuk pada konsep power over (kekuasaan yang meliputi, atau dominasi), dimanakekuasaan dipandang sebagai alat strategis untuk mencapai tujuan. Sedangkan bagian kedua menunjukkan power to (kekuasaan terhadap sesuatu, atau pemberdayaan), yaitu kekuasaan dimaknai sebagai perwujudan otonomi masyarakat, melalui proses intersubyektif yang mampu menciptakan solidaritas bersama.

Bagian I terdiri atas empat bab. Bab Power and Domination: The Dominant Perspective menjelaskan state of the art dari kemunculan konsep kekuasaan yang meliputi (power over), yang menggapai tujuan melalui mobilisasi sumberdaya. Definisi kekuasaan semacam ini secara tegas muncul dalam pemikiran Parsons. Ia mendudukkan kekuasaan sejajar dengan otoritas, sehingga memiliki keresmian dan legitimasi untuk mendesakkan keinginan ke orang lain, sekalipun orang itu tidak menginginkannya. Saya menduga konsep kekuasaan semacam ini masih diikuti dalam banyak tulisan di Indonesia.

Sementara Parsons meletakkan kekuasaan pada suatu struktur sosial AGIL (adaptation, goal attainment, integration, latency), Giddens menempatkan kekuasaan dan otoritas ke dalam interaksi sosial. Dalam interaksi sosial, agensi tidak saja tergantung kepada struktur sosial yang lebih luas, melainkan dalam konteks ketergantungan itu sang agensi juga mampu menyusun stuktur baru. Stewart mencatat, bahwa dalam teori strukturasi memang proses liberasi mulai muncul (dan ini juga memberikan ide tentang ruang pemberdayaan), namun pemikiran utama Giddens tetap berupa dominasi struktur terhadap agensi.

Didasari oleh pemikiran Nietszhe, terutama mengenai keinginan untuk berkuasa (will to power), pemikiran Foucault tentu saja lebih menekankan liberasi tersebut. Akan tetapi, lagi-lagi Foucault masih mengidap pandangan tentang dominasi pihak yang berkuasa kepada pihak lain yang dikuasai. Pendapat ini terutama disandarkan kepada inkonsistensi antara konsep menuju kekuasaan, tetapi tanpa menganalisis adanya konsep kebenaran yang hendak dituju (diinginkan) serta liberasi dari dominasi untuk mencapai kebenaran itu. Melalui pelembagaan kekuasaan yang diikuti dengan hukuman (punishment), maka dominasi itu kemudian diwujudkan dalam kehidupan sehari-hari, dimanaindividu telah membatasi dirinya sendiri (mengingatkan diri akan adanya hukuman) dalam berpikir dan bertindak. Namun demikian, Stewart masih menyisakan harapan akan adanya peluang penyusunan politik pemberdayaan dari konsep kekuasaan ala Nietszhe dari Foucault. 
Sampai di sini muncul perbedaan pandangan saya dari Stewart. Dengan membaca beragam teori-teori pascamodernisme (post-modernism theories), saya berpandangan bahwa telah muncul suatu pandangan politik baru, yang bisa disebut sebagai politik pascamodernisme. Pandangan politik Foucault sendiri telah dikembangkan oleh sosiolog lain, dan sudah lazim pula menyebut pemikiran politik pascamodernisme tersebut sebagai kekuasaan yang menciptakan solidaritas sosial dan pembebasan, bukan kekuasaan yang mengkooptasi (Foucault, 2002; Best dan Kellner, 2003). Pemikiran liberasi ini sejalan dengan kaidah lain dalam pascamodernisme tentang penolakan terhadap teori agung (grand theory) dan aturan yang memusat, sebaliknya menghargai posisi-posisi politis maupun teoritis yang lokal.

Berikutnya Stewart mengemukakan konsep kekuasaan dari Mann. Untuk sampai kepada kebutuhan akan konsep kekuasaan, mula-mula masyarakat (society) dipandang sebagai jaringan kekuasaan yang saling berimpitan maupun saling tumpang tindih. Adapun sumber kekuasaan pada masa modernitas akhir terdiri atas ideologi, ekonomi, militer dan politik. Agar kekuasaan tersebut terlegitimasi, maka masing-masing sumber kekuasaan tersebut kemudian menyusun lembaga dan organisasi masing-masing. Di samping itu, masingmasing sumber kekuasaan tersebut juga menciptakan mekanisme kontrolnya masing-masing. Untuk melihat proses penggunaan sumber-sumber kekuasaan, Mann meminjam teori-teori tentang elite kekuasaan. Dengan cara ini, sayangnya, Mann menjadi sulit memperlihatkan pola-pola pemberdayaan dari lapisan bawah.

Bab Analysing Power and Domination berisi alternatif pemaknaan kekuasaan, sebagaimana dikemukakan oleh Hannah Arendt dan Habermas. Dari sini muncul kerangka yang menghubungkan kekuasaan dengan komunitas, kepentingan, dan dominasi. Struktur dominasi tidak bisa dipandang secara monolitik, mekanistik, dan mampu menyeimbangkan dirinya sendiri. Lebih tepat memandang struktur dominasi sebagaimana wadah-wadah untuk bertahan hidup (sites of struggle). Hubungan ketidaksamaan muncul dalam antara proses resolusi konflik dan distribusi sumberdaya. Di antara kedua proses itu tersembul peluang transformasi sosial melalui proses pemberdayaan. Dialektika ini terujud dalam pola kelompok dominan saat berhubungan dengan komunitas, baik yang terbentuk karena kesamaan kepentingan maupun saling kenal antar anggota.

Bab Capitalism and Struggle: From the Factory to the Smart Machine berisi dialektika antara pemberdayaan dan dominasi dalam wadah kapitalisme. Dalam sejarah kapitalisme, maka di dalamnya terdapat tiga wadah untuk persaingan mempertahankan kehidupan, yaitu pasar, organisasi produksi, dan organisasi politik. Sampai saat ini dominasi masih tumbuh melalui mobilisasi kapital.

Sedangkan bab States: Domination or Empowerment? berisi dialektika pemberdayaan dan dominasi dalam wadah negara. Negara dipahami sebagai system hukum yang memiliki wilayah teritorial sebagai basis legitimasi 
dominasi tersebut. Akan tetapi dalam masa modernisme akhir, melalui globalisasi sedang terjadi proses keruntuhan kekuasaan Negara (powerless state). Sebagai konsekuensi berikutnya, tumbuh relevansi peran masyarakat dan swasta.

Berikutnya kita masuk ke bagian kedua dari buku ini, mengenai alternatif untuk memandang kekuasaan sebagai pemberdayaan. Bab Capitalism, States and Public Sphere I: Habermas' Political fourney berisi hubungan antara kapitalisme dan demokrasi. Di sini dikemukakan pandangan Habermas menurut sejarahnya. Habermas mengemukakan pandangan sistem (system, dalam sosiologi umumnya disebut struktur) dan dunia-kehidupan (life-world, merujuk kepada individu atau semacam agensi). Dominasi ditunjukkan oleh kolonisasi aturan-aturan sistem ke dalam dunia-kehidupan. Untuk mengatasi dominasi ini, maka perlu dibuka ruang yang bebas bagi terwujudnya komunikasi yang dialogis. Ruang publik (public sphere) tersebut merupakan jawaban Habermas sebagai bentuk demokrasi (terutama oleh life-world) melawan dominasi negara (kolonisasi system).

Bab Capitalism, States and Public Sphere II: Empowerment in the Public Sphere berisi pembatasan dalam kerangka pemikiran Habermas di atas. Dari data lapangan diketahui bahwa konsep tindakan komunikatif yang dilakukan tanpa saling memaksa ternyata tidak berlaku. Saya sendiri melihat pandangan Habermas tentang tindakan komunikatif secara bebas mirip dengan pandangan ekonom tentang pasar bersaing sempurna. Kedua konsep tersebut bersifat ideal, yang tidak (mungkin) terjadi dalam empiri sehari-hari. Bahwa Habermas menciptakan konsep ideal tersebut, menunjukkan ciri kental dari mazhab Frankfurt. Dalam mazhab pengetahuan ini, kritik terhadap suatu teori atau masyarakat hanya mungkin terwujud jika ada suatu pandangan dasar yang mutlak, sehingga bisa menjadi pedoman bagi siapa saja untuk menilainya. ${ }^{3}$ Tidak heran analisis Habermas banyak didasari oleh analisis filsafat juga, karena pandangan mendasar bisa dikelola oleh filsafat. Namun justru di sinilah muncul persoalan untuk menurunkannya ke tataran praksis.

Bab Citizenship: Constituting Political Commmunity berisi hubungan antara kekuasaan negara dan politik perbedaan (politics of difference). Kewarganegaraan sebetulnya sudah menjadi isu sentral sejak dari politik modernitas. Perbedaannya dari masa modernitas akhir ialah, sementara dahulu kewarganegaraan dikaitkan dengan hal-hal yang bersifat pasif dan warga yang didominasi oleh negara, maka kini muncul pemikiran tentang perbedaan. Dalam pemikiran ini disadari adanya perbedaan di antara warga negara sendiri, misalnya menurut gender maupun kebudayaan. Dengan mengusung perbedaan

\footnotetext{
3 Bandingkan dengan pandangan pascamodernisme, yang tidak memiliki asumsi untuk mengambil pandangan mutlak dalam proses analisis masyarakat maupun ilmu sosial (Foucault, 2002). Bahkan lebih lanjut lagi, mendasarkan pencarian berbasis filsafat dimaknai sebagai khas budaya Barat (terutama Eropa). Bagi masyarakat lain, di wilayah lain, landasan yang paling mendasar mungkin tidak (perlu) digali lewat filsafat, melainkan berbasis budaya pengetahuan lainnya.
} 
ini, isu kewarganegaraan kini dikaitkan dengan kekuatan komunitas untuk bersaing atau berkomplemen dengan negara dalam ruang hidup yang sama.

Bab New Social Movements: Politics of Identity and Politics of Distribution berisi uraian sejauhmana peluang transformasi menuju pemberdayaan dalam diwujudkan, agar menjadi alternatif atau pelengkap bentuk-bentuk kelembagaan dominan. Gerakan sosial dipandang sebagai upaya untuk memobilisasi nilai-nilai imanen yang sebetulnya selalu ada dalam komunitas. Kelebihan dari gerakan sosial ialah kemampuannya untuk menumbuhkan solidaritas yang melewati batas-batas teritorial.

\section{Cendekiawan dalam Orde Baru}

Sebagaimana disebutkan di muka, saya berminat menggunakan pola pemikiran Stewart (2001) untuk menelaah karya Dhakidae (2003). Tesis utama yang hendak dibangun Dhakidae ialah, bahwa cendekiawan merupakan variabel yang terikat oleh negara, kapital, dan kebudayaan. Sampai di sini terlihat kesejajarannya dengan kerangka pemikiran Stewart perihal kekuasaan sebagai strategi untuk mencapai tujuan (power over), kecuali bahwa Dhakidae menambahkan sebuah variabel lagi, yaitu kebudayaan, yang menurut Stewart sudah tercakup ke dalam dua variabel lainnya. Sayang Dhakidae tidak secara konsisten menggunakan dua variabel bebas tersebut, melainkan kemudian condong kepada dominasi negara (Orde Baru) terhadap cendekiawan.

Selalu di sela-sela penulisannya tentang sosok cendekiawan sejak masa penjajahan Belanda, dalam organisasi akademis, organisasi keagamaan, maupun industri media massa, Dhakidae juga merumuskan resistensi yang dilakukan oleh (sebagian kecil) cendekiawan. Akan tetapi kita tidak mendapati kekuatan cendekiawan tersebut di hadapan negara. Jika hal ini dibaca sebagai kelemahan analisis Dhakidae yang cenderung menampilkan sisi power over daripada power to, maka kekurangan penampilan fakta pemberdayaan cendekiawan bisa dipahami. Namun demikian, ada pula peluang kekurangan Stewart dalam menawarkan kerangka pemikiran untuk menganalisis cendekiawan Indonesia di masa Orde Baru tersebut. Saya sendiri menafsirkan hal itu sebagai konsekuensi pemakaian teori diskursus dari Foucault (2002) oleh Dhakidae, yang lebih menekankan kontrol (atau sebaliknya pemberdayaan) secara individual dan dalam kehidupan sehari-hari. Dengan demikian suatu struktur atau jaringan sosial di antara cendekiawan kritis tidak sempat dikemukakan, padahal bagaimana cendekiawan yang sekritis Gus Dur (Dhakidae setidaknya pernah menggolongkannya ke dalam cendekiawan kritis dalam diskursus keagamaan) tetap bisa bertahan di Indonesia, jika tanpa jaringan kuat publiknya disertai jaringan kekuasaan dan modal dari luar negeri? Dalam hal ini Rendra juga pernah mengemukakan hal yang sama tentang dirinya, atau refleksi A Heryanto terhadap perbedaan perilaku universitas terhadap Arief Budiman (kemudian menjadi profesor di luar negeri) yang lebih hati-hati dan 
dirinya (yang menjadi dosen di luar negeri) yang terkesan lebih semena-mena, usai pertarungan dengan pimpinan Universitas Kristen Satya Wacana.

Namun sesungguhnya ujaran Dhakidae tentang relasi cendekiawan dan kekuasaan (negara dan kapital), melalui terutama analisis diskursus, tetap menghasilkan kesimpulan yang menarik. Dalam Bab Satu, Dhakidae menghindari perdebatan tentang definisi cendekiawan sebagai suatu status sosial yang statis. Sebaliknya ia selalu mendefinisikan cendekiawan selalu dalam relasi dengan kekuasaan negara dan modal. Pola hubungan itulah yang ditegaskannya melalui kerangka pemikiran kekuasaan menurut Benedict R'OG Anderson (kekuasaan itu mutlak dan satu), Foucault (kekuasaan itu tersebar, bahkan bisa bersifat individual), serta Gouldner (ada hubungan erat antara diskursus dan kekuasaan). Sedangkan Orde Baru didefinisikan sebagai negara neofasis (bagian ini agak janggal untuk dikaitkan dengan pemikiran kekuasaan sebelumnya).

Dari Foucault, Dhakidae meminjam metode arkeologi pengetahuan. Tidak heran pada Bab Dua ia menjelaskan hubungan antara cendekiawan dengan pemerintah kolonial Hindia Belanda. Di sini dikemukakannya kekuasaan diskursus negara (kolonial) terhadap cendekiawan masa itu. Kartini merupakan contoh yang menarik. Dalam diskursus formal saat ini, tulisan-tulisan Kartini dimaknai sebagai bentuk pembebasan yang berhasil dari seorang pribumi Indonesia. Akan tetapi analisis diskursus oleh Dhakidae bergerak menuju kesimpulan, bahwa tulisan-tulisan Kartini, dengan berbahasa dan memakai pola pikir Belanda yang fasih, justru menjadi tolok ukur keberhasilan kolonialisme, yaitu keberhasilan politik etis. Hal yang sama juga terjadi pada Soekarno, Hatta, Sjahrir, Ki Hajar Dewantara. Bagi Dhakidae, tulisan dengan bahasa rakyat dan logika yang bisa diterima rakyatlah yang menunjukkan resistensi dari kolonialisme Belanda, misalnya karya Tirto Adisoeryo, Marcodikromo, dan Tan Malaka.

Dalam Bab Tiga dikemukakan argumen atas penggunaan konsep neofasisme. Secara khas fasisme di Indonesia dipengaruhi oleh modal. Ciri fasisme muncul dari corak kediktatoran militer, yang kemudian hendak menumpas pluralitas dalam ekonomi, politik, sampai kebudayaan. Dhakidae menganalisis kesejajaran sejarah (diskursus) masa kolonialisme Hindia Belanda, ke dalam masa Orde Baru (1966-1998).

Sampai di sini saya perlu membaca lebih kritis. Agak mengherankan bahwa arkeologi pengetahuan menghasilkan kesejajaran sejarah. Hal ini mungkin terjadi karena diskursus baru memang dimulai sejak masa penjajahan Hindia Belanda, tanpa pernah hilang. Jika demikian, maka arkeologi pengetahuan perlu ditarik ke masa yang lebih jauh lagi, sehingga diketahui adanya perubahan diskursus. Peluang lainnya ialah, analisis yang belum tepat tentang perbedaan diskursus masa Hindia Belanda dan Orde Baru. Saya pribadi cenderung melihat pada kemungkinan terakhir. Pola hubungan negara dan kapital pada masa Hindia Belanda (negara kolonial, kapital dari dalam negeri 
induk: Belanda) berbeda dari hubungan negara dan kapital masa Orde Baru (negara militer, kapital dari luar negeri atau bank yang global). Diskursus kolonialisme (perkembangan pada level Indonesia atau Indonesia-Belanda) berbeda dari diskursus Orde Baru (perkembangan pada level Indonesia atau level internasional).

Bab Empat berisi penaklukan negara terhadap lembaga-lembaga cendekiawan. Ilmu sosial menjadi sumber kekuasaan, dan berguna untuk mengimpitkan dunia ilmuwan sosial dengan negara. Dengan menggunakan kesejajaran sejarah, Dhakidae menunjukkan "persamaan" penggunaan bahasa Belanda pada masa kolonialisme, sejajar dengan penggunaan "bahasa" statistika menurut teknokrat Orde Baru. Dalam hal ini, bahkan jurnal yang dipandang berbobot bagi ilmuwan sosial, Prisma, juga akhirnya tenggelam ke dalam bahasa-bahasa alat dominasi Orde Baru. ${ }^{4}$

Bab Lima berisi dominasi diskursus lewat bahasan dan media massa. Ini bab yang secara jelas menunjukkan sumber politik, kapital dan kebudayaan yang digunakan negara untuk mendominasi cendekiawan. Upaya pemberdayaan dinafikan melalui slogan kebebasan yang bertanggung jawab, yang bisa dibaca sebagai tidak ada kebebasan melainkan dominasi diskursus oleh negara.

Bab Enam berisi dominasi negara dalam diskursus keagamaan. Dalam diskursus ciptaan Orde Baru, agama merupakan lawan yang berada pada wadah yang sama dengan negara (site of struggle). Oleh sebab itu negara memerintahkan organisasi kejaksaan untuk mentes kebenaran ala agama.

Bab Tujuh berisi serangkaian kesimpulan. Dhakidae berkesimpulan bahwa negara Orde Baru telah melakukan upaya pengambilalihan diskursus, padahal pembentukan diskursus itu juga menjadi peran cendekiawan (berada pada kesamaan sites of struggle). Bab itu juga berisi dominasi negara Orde Baru, yang memiliki data arkeologis dari masa penjajahan Hindia Belanda. Di sana-sini, tercerai berai, sempat muncul pula perlawanan dari cendekiawan itu sendiri.

\section{Ilmu Sosial dan Kekuasaan}

Sementara Dhakidae (2003) mendalami dominasi negara Orde Baru terhadap cendekiawan, Hadiz dan Dhakidae (eds.) memperdalam aspek-aspek khusus perkembangan ilmu sosial. Buku ini merupakan salah satu buku yang diterbitkan untuk memperingati 50 tahun Ford Foundation di Indonesia. Buku lainnya dalam seri ini ialah Environmental Politics and Power in Indonesia, Indonesian Arts Since Independence: Changing Context, Content, and Careers, dan People Population and Policy in Indonesia.

\footnotetext{
${ }^{4}$ Temuan Dhakidae ini menarik, jika dikaitkan dengan upaya Sajogyo (2004) untuk mengembangkan metode kualitatif, yang semakin kuat dikemukakan pasca-Orde Baru. Di sini penggunaan metode kualitatif dapat dibaca sebagai upaya pemberdayaan ilmuwan sosial terhadap dominasi diskursus Orde Baru. Bahwa Sajogyo memperkuat kecenderungan ini akhir-akhir ini, bukan semasa Orde Baru, dapat dipahami sebagai hasil pemikirannya untuk mengetes sejauhmana reaksi negara terhadap ilmuwan sosial (White, 2005). Dulu negara terlalu mendominasi, tetapi sekarang dominasi itu menurun.
} 
Sebagian besar isi buku inipun berkisar pada masa Orde Baru, kecuali dalam aspek khusus, contohnya sejarah agraria sejak masa penjajahan Hindia Belanda. Sebagai hasil karya editing, pola pemikiran dalam buku ini beragam, namun dipandang penting ialah mengemukakan pandangan kritis terhadap perkembangan ilmu sosial di Indonesia. Dalam pada itu, kekuasaan berusaha diletakkan sebagai variabel bebas yang mempengaruhi isi dan bentuk ilmu sosial di Indonesia saat ini.

Perkembangan penting semasa Orde Baru di antaranya tentu saja peranan donor asing. Sebagai pekerjaan lain yang tergantung kepada pilihan-pilihan donor, ilmu sosial di Indonesia juga mengalami hal yang sama. Donor asing yang masuk memalui departemen telah mengajak ilmuwan sosial di Indonesia untuk menjadi pejabat. Hal ini turut membentuk proses birokratisasi ilmu sosial di Indonesia. PM Laksono (Social Science Association) dengan jelas menunjukkan kepentingan negara terhadap organisasi-organisasi keilmuan. Begitu pula sebaliknya, jabatan pimpinan dari organisasi keilmuan tersebut diimpikan karena menjadi batu locatan untuk memperoleh jabatan dalam pemerintahan. Terdapat contoh ISI (Ikatan Sosiologi Indonesia) yang pada awalnya dijabat oleh Menteri Kependudukan, agar memudahkan hubungan antara soisolog dan penguasa. Bahkan Ketua ISEI (Ikatan Sarjana Ekonomi Indonesia) selalu menjadi kandidat menteri dalam kabinet Soeharto.

Dalam kasus sosiologi pedesaan, pilihan buku-buku teks pada awalnya juga terkait dengan donor. B White (Between Apologia and Critical Discourse: Agrarian Transition and Scholarly Engagement in Indonesia) menunjukkan bahwa bukubuku AT Mosher semula digunakan dalam pengajaran penyuluhan pertanian, lebih karena pilihan buku yang dikirim oleh ADC (Agricultural Development Council) di Amerika Serikat memang buku-buku karya direkturnya tersebut.

Tidak saja pada pemerintah, donor juga berperan dalam mengarahkan sasaran kajian dari LSM. M Ganie-Rochman dan R Achwan (Inclusion dan Exclusion: NGOs and Critical Social Knowledge) menunjukkan, bahwa dalam iklim yang kering untuk pertumbuhan ilmu sosial, (sebagian) LSM memperoleh fasilitas yang lengkap dari hal peralatan elektronik sampai buku-buku bacaan. Ini memberikan kekuatan bagi LSM untuk mengembangkan ilmu sosial tersendiri, yang bersifat kritis kepada pemerintah. Akan tetapi temuan ini masih perlu dikritisi, karena kedua editor sendiri menyodorkan ragam penelitian lainnya, yang menunjukkan ketergantungan LSM kepada diskursus dan finansial donor asing. White dalam buku ini juga menunjukkan, bahwa ilmuwan sosial dalam lingkaran LSM masih juga belum mampu membangun suatu teori yang kokoh. Keadaan ini, bagi White, masih belum menunjukkan alternatif penyusunan ilmu sosial dari kalangan LSM.

Keberadaan donor juga terkait dengan sejarah geopolitik yang terdapat di Indonesia. Dalam konteks perang dingin, pola pikir modernisasi diterapkan sebagai diskursus ilmu sosial di Indonesia. Ilmuwan Amerika Serikat, menggantikan ilmuwan dari Belanda, mulai masuk ke Indonesia sejak awal 
masa kemerdekaan. Mereka memberika ide-ide modernisasi dalam penelitian, teori, maupun implikasi kebijakan. Bahkan setelah PKI dilarang pada tahun 1966, kajian Marxist bersifat ambigu, karena dilabeli larangan sama halnya dengan PKI. Menarik untuk mencatat, bahkan teori ketergantungan yang Marxist, ketika disampaikan dalam publik Indonesia, diikuti dengan argumenargumen populis, dan sebagian bergumen relijius. Bahkan sebagian ilmuwan tersebut (Dawam Rahardjo dan Adi Sasono) menjadi tokoh ICMI yang dibentuk oleh negara Orde Baru.

Pengaruh Amerika Serikat tersebut juga terasa dalam hal penguatan metodologi kuantitatif. Ini juga dikuatkan oleh kepentingan negara dalam menyukseskan pembangunan. Sebagaimana dikemukakan oleh Dhakidae (2003) di atas, bahasa statistika di sini memiliki konteks pada kepentingan Amerika Serikat -di samping kepentingan negara Orde Baru.

Pengaruh sejarah global pada masa kini terwujud dalam bentuk neoliberalisme. Sejalan dengan itu, teori-teori yang berkembang di Indonesia juga merupakan salah satu perwujudan dari paham ini. Dalam hal ini perlu disebut konsep modal sosial, partisipasi, dan pemberdayaan yang diimpor dari Bank Dunia. Memang dalam internet terdapat kemudahan yang hampir-hampir tidak diperkirakan, dimanaBank Dunia memberikan terlalu banyak bahan untuk kajian ilmu sosial (bisa dibaca sebagai upaya untuk melakukan hegemoni). Konsep-konsep ini memiliki implikasi neoliberal, dimanamasyarakat dipandang sebagai individu yang memiliki tingkah laku (behaviour) yang mudah diramalkan, yaitu sebatas sebagai makhluk ekonomis.

Selain donor, pemerintah (negara) sendiri memiliki kepentingan untuk menormalkan ilmu sosial agar sejalan dengan kepentingan negara. Dalam pengelolaan perguruan tinggi, presiden memiliki hak prerogatif untuk mengangkat dan memberhentikan rektor (H Nugroho di buku ini: The Political Economy of Higher Education: The University as an Arena for the Struggle of Power). Sementara itu, salah satu peran penting rektor ialah sebagai aparat pemerintah yang bertugas menormalkan kampus dari tindakan politis mahasiswa dan dosen.

Khusus tentang perkembangan sosiologi pedesaan (tulisan White dalam buku ini), kondisinya tidak berbeda jauh dari perkembangan ilmu sosial lainnya. Yang tidak sempat ditinjau oleh karangan lainnya ialah, bahwa White mengemukakan masa-masa keemasan penggalian pengetahuan kritis tentang masyarakat pedesaan pada masa 1950-1960-an. Sebetulnya White sempat mencatat dua kecenderungan pengembangan soisologi pedesaan, yaitu berkutat dengan teori, dan mencatat dengan detil hasil kajian lapangan. Keduanya memiliki akar sejarah dari masa penjajahan Hindia Belanda. Kajian teori dilakukan oleh ilmuwan Belanda (dan kemudian Amerika Serikat). Sarjana Indonesia sendiri sampai saat ini lebih banyak tertuju pada upaya untuk mendokumentasikan hasil kajian lapangan secara detil. Saya pikir tradisi inilah yang antara lain menghambat perkembangan ilmiah (penciptaan teori baru) sosiologi pedesaan. Bahkan upaya penggunaan statistika dalam penelitian 
sosiologi pedesaan tidak bisa dipandang sebagai generalisasi, yang akan menelorkan teori baru, melainkan sekedar upaya untuk menjelaskan hubungan antarkejadian dalam lokasi penelitian yang terbatas itu sendiri.

Seperti halnya ilmu sosial lain yang kehilangan daya kritisnya selama masa Orde Baru (menjadi variabel terikat dari kepentingan pembangunan, sebagaimana dikemukakan oleh Kleden, 1987), sosiologi pedesaan juga mengalaminya secara berkepanjangan. Dominasi negara sampai-sampai muncul dalam penyusunan subyek kajian. Sajogyo (1996) pada masa ini mengemukakan kajian sosiologi pedesaan ialah peluang berusaha dan bekerja, masalah agraria, peranan wanita, grup dan komunitas, nilai-nilai sosial-budaya, dan kependudukan. Diskursus semacam itu memang tidak menunjukkan wacana kritis. Tidak heran White mengomentari penolakan Sajogyo tentang dominasi (dengan menunjuk kebebasan mahasiswa untuk memilih topik kajian) sebagai hal yang wajar manakala mahasiswa juga tidak tergerak untuk memilih topik yang kritis.

Satu hal yang sama-sama dikemukakan dalam tiga buku ini ialah bahwa masa kini sedang bergerak ke arah liberasi, atau pemberdayaan. Di kalangan ilmuwan di dunia, pemberdayaan tersebut tidak sekedar terlihat dalam beragam wacana kritis, melainkan juga pertumbuhan metodologi yang mengarah kepada kajiankajian etis kemanusiaan, yaitu hak-hak asasi manusia, demokrasi, dll (Denzin dan Lincoln, 2000). Dalam kasus Indonesia, hal ini ditunjukkan oleh ruang dan waktu reformasi. Pemberdayaan di kalangan ilmuwan itu tercermin dari susunan diskursus sosiologi pedesaan yang diperbarui sendiri oleh Sajogyo (2004), dan di sini kekritisan itu mulai muncul: transisi agraria yang mengarah ke pemerataan peluang usaha dan peluang kerja, upaya merubah tujuan dan cara-cara mengelola governance dalam beragam jenis lembaga/organisasi dan masyarakat, perkembangan penduduk dan kehidupan sosial yang peka lingkungan. Namun sekali lagi perlu disadari, bahwa di Indonesia, menurut Hadiz dan Dhakidae (eds) reformasi belum memunculkan ilmuwan kritis maupun teori dari ilmuwan Indonesia. Dalam kasus sosiologi pedesaan, Wahite mencatat, bahkan akademisi yang berkutat di LSM untuk mengembangkan diri ternyata juga belum menghasilkan karya yang menonjol, apalagi berujud teori sosiologi pedesaan ala Indonesia.

\section{Daftar Pustaka}

Angus, Stewart. 2001. Theories of Power and Domination: ThePolitics of Empowerment in Late Modernity. Sage Publications. London.

Best, S dan D. Kellner. 2003. Teori Posmodern: Interogasi Kritis, terjemahan dari Postmodern Theory: Critical Interrogations. Boyan. Malang.

Denzin NK, dan YS Lincoln. 2000. The Discipline and Practice of Qualitative Research. Di dalam NK Denzin dan YS Lincoln, eds. Handbook of 
Qualitative Research. Second Edition. Sage Publications. Thousand Oaks.

Dhakidae, D. 2003. Cendekiawan dan Kekuasaan dalam Negara Orde Baru, Gramedia. Jakarta.

Foucault, M. 2002. Pengetahuan dan Metode: Karya-karya Penting Foucault. Terjemahan dari P Rabinow, ed. Aesthetics, Method and Epistemology: Essential Works of Foucault 1954-1984. Jalasutra. Yogyakarta.

Hadiz, VR dan D Dhakidae, eds. 2005. Social Science and Power in Indonesia, Equinox dan ISEAS. Singapore.

Kleden, I. 1987. Sikap Ilmiah dan Kritik Kebudayaan. LP3ES. Jakarta.

Sajogyo. 2004. Dari Praktek ke Teori dan ke Praktek yang Berteori. Makalah tidak dipublikasikan.

, 1996. Kata Pengantar, in Sajogyo, et.al. Panen 20th Ringkasan Tesis dan Disertasi 1975-1994. Program Studi Sosiologi Pedesaa. Program Pacasarjana Institut Pertanian Bogor. Puspa Swara. Jakarta.

Sharrock, WW, JA Hughes dan PJ Martin. 2003. Understanding Modern Sociology. Sage Publications. London.

Stewart, A, 2001. Theories of Power and Domination: The Politics of Empowerment in Late Modernity. Sage Publications. London.

Wallace, RA and A. Wolf. 1999. Contemporary Sociological Theory: Expanding the Classical Tradition. Fifth Edition. Prentice Hall. New Jersey.

White, B. 2005. Between Apologia and Critical Discourse: Agrarian Transition and Scholarly Engagement in Indonesia, in VR Hadiz dan D Dhakidae, eds. Social Science and Power in Indonesia. Equinox dan ISEAS. Singapore. 